\title{
A critical evaluation of the development and use of values in coaching
}

\author{
William Crossan*, Miloš Bednář
}

Faculty of Physical Education and Sport, Charles University, Prague, Czech Republic

* Corresponding author: crossan@ftvs.cuni.cz

This work represents original scientific scholarship which is not under review with any other journals. The authors have not received any outside funding or grants in relation to this research.

\begin{abstract}
The use of values in the coaching process by Czech basketball coaches is examined in light of the development of intrinsic, added and instrumental values in sport through history. Hard work and respect were seen to be dominant guiding and developmental values of the 73 FIFA licensed coaches surveyed, with fun and moral values rarely given mention. The argument is made that coaches must change to succeed in engaging today's athletes, to maintain athletes in their clubs, and even for future competitive balance. Values-driven leadership, as has proven successful in the business world, is proposed as a way forward for coaches striving to build players, teams, clubs and a sport. The intentional implementation of incarnational values by a coach can have an amplification effect on the team and club to engage as many athletes as possible in "good" sports.
\end{abstract}

\section{KEYWORDS}

values; sport coaching; basketball; Czech Republic; positivity

DOI

$10.14712 / 23366052.2018 .8$

(c) 2018 The Authors. This is an open-access article distributed under the terms of the Creative Commons Attribution License (http://creativecommons.org/licenses/by/4.0), which permits unrestricted use, distribution, and reproduction in any medium, provided the original author and source are credited. 


\section{INTRODUCTION}

Values-driven leadership is a well-researched realm of academic and practical study (Dean, 2008; Fernandez \& Hogan, 2002; Grojean, Resick, Dickson, \& Smith, 2004; Kluckhohn, 1951). Sport coaching from a values foundation also has a significant body of research (Duda, Balaguer, Jowett, \& Lavallee, 2007; Janssen \& Dale, 2002; Stupuris, Šukys, \& Tilindienè, 2013; Yi-Ling Lai \& McDowall, 2014). Even more significant is that sport is still largely assumed to be loaded with positive value, and coaches are often assumed to be led by and aware of said values. Parry has referred to sport as a laboratory "for values experiments" (2010, p. 320). Much research shows that these values are often forgotten or suppressed by other factors driving today's sport culture (Burton \& Welty Peachey, 2014; Crone, 1999; Peel, Cropley, Hanton, \& Fleming, 2013; Sagas \& Wigley, 2014). Other research suggests that many of the values which we expect to be conveyed via sport are in reality not inherent to the sport, but rather added onto sport (Fraleigh, 1983; Martínková, 2012). With this in mind we have undertaken to examine the awareness and use of values in coaching basketball in the Czech Republic. Using surveys we assess the prevalence of values-driven coaching, the values chosen for emphasis, and the way in which these values are (or are not) conveyed across varying age and competition levels in Czech basketball.

It was expected that most Czech basketball coaches do not lead from a set of predetermined values. However the values stated, whether true guiding values, or only lightly held ideals, flow from a cultural and historical framework from which the coach defines success (Callary, Werthner, \& Trudel, 2013; Camiré, Trudel, \& Forneris, 2014; Hassanin \& Light, 2014; Kretchmar, 1994; Lumpkin, Stoll, \& Beller, 2002). These values need to be evaluated from a developmental perspective as well as from a management perspective. "Sport managers must learn to identify and evaluate values related to the bureaucratic and business aspect of sport. They must then seek to evoke positive change so ethical behaviour and practices are championed" (DeSensi, 2010, p. 16).

This study was motivated by the experience of four Czech FIBA A level basketball coaches in the USA for a tour of NCAA basketball. One of the things repeatedly observed by the coaches was the clear prevalence of values emphasized on almost every team visited. Most teams had their 3-5 values painted on the walls of their locker rooms. Coaches frequently began practice by telling a story which emphasized one of the values which the staff felt was currently being neglected. The values were on team t-shirts, in media guides, and in their social media posts. Each time we sat down with a coach one-on-one, they began to tell us about their values very early in the conversation. This element of a values-driven coaching approach was thought by the Czech coaches to be lacking in the Czech basketball environment. Thus this study has been undertaken at the request of the Czech Basketball Federation to examine this observation and propose a way forward in the Czech basketball context.

Here are a few examples of the values stated and emphasized by the NCAA basketball programmes visited:

- Humility, Passion, Unity, Servanthood, Thankfulness - University of Virginia

- Hard Work, Selfless, Honest, Resilient, Caring, Positive, Grateful - Duke University 
- Commitment, Trust and Caring - Davidson University

- Care, Commitment, Servant Leadership, Confidence, Discipline and Perspective University of North Carolina

- Hard work, Effort, Sacrifice and Accountability - Wake Forest University

We are certainly not trying to say that in the Czech Republic basketball needs to be played or developed the American way, but this emphasis (or lack of emphasis) on values is nonetheless worthy of reflection. The American sport system is closely tied to the educational system, so the idea that a coach is also educating players for life is inherently more prevalent and expected (Brand, 2006; Burton \& Welty Peachey, 2014; Hassanin \& Light, 2014; Parry, 2010). Additionally, many of these coaches are being paid millions of dollars to create winning teams. This market-driven sports environment, with its high emphasis on recruiting and retaining the best athletes, often draws not only on the best sport practices, but also the best business practices in building teams. Though NCAA players are not professionals, the level of facilities, amount of media attention, hours of practice time, etc. often far exceed the professional conditions common in Europe. The NCAA coaches are primarily being hired and fired based on their wins and losses, not based on how they educate players for life. Thus we would like to consider whether there is a pragmatic, managerial, and winning logic for coaches to develop social character. We will review the development of values-based leadership in sport before turning to our examination of the use of values in coaching Czech basketball.

\section{LITERATURE REVIEW}

\section{Sports build character}

It is traditionally accepted, and often generally stated, that sports build character. However many studies show a different reality (Doty, 2006; Gerdy, 2000; Kleiber \& Roberts, 1981; Rees, Howell, \& Miracle, 1990; Sage, 1998). While the acquisition of motor skills and sport-specific abilities are significant benefits of sport involvement, other elements contributing to athletes' development, such as life skills and values, must also be considered. Several longitudinal studies have shown that the longer athletes stay in sport, the more morally calloused they become (Beller \& Kay Stoll, 1995; Russell, 2011; Stoll \& Beller, 2012). Beller and Stoll propose that the increasing commercialization, emphasis on winning, early specialization and limited non-sport relationships all contribute to a decrease in moral reasoning and moral development of athletes (1995). The Josephine Institute found that "boys and girls who play sport are actually more likely to cheat in school, and engage in other dishonest, deceptive and dangerous practices without regard for the rules or traditional notions of fair play" (Josephson Institute, 2006, p. 1). Poor sportsmanship, decline in moral reasoning, discrimination, racism, aggression, and win-at-all cost attitudes, which distort fair play, have also been associated with sport participation (Bredemeier, Weiss, Shields, \& Cooper, 1987; Burton \& Welty Peachey, 2014; May, 2001). So we must ask the question, "What is good in sports?" or stated differently, "What values does sport truly inhabit?"

Baier laid out two characteristics which make sports "good" in a moral sense as being meant for everybody and for the good of everyone alike (Baier, 1965). Many 
attempts to define this "good" in the sense of values have followed. Beller and Stoll define morally good as "the notion that we as a people judge certain motives, intentions, and actions as acceptable and positive as compared to other motives, intentions, and actions which are judged unacceptable" (1995, p. 353). In history this moral good has often been defined in terms of values. We can sort the definition of values into (minimally) five groups:

1. Values are generally valid norms of human behaviour.

2. Values are subjects of our effort.

3. Values are special traits or qualities.

4. Values are a motivational construct. They refer to the desirable goals which people strive to attain.

5. Values transcend specific actions and situations. They are abstract goals.

The most influential contemporary definition proceeds from these last two, and says that values are "desirable trans-situational goals that vary in importance, and serve as guiding principles in the life of a person or other social entity" (Development of this definition comes from Kluckhohn (1951) to Rokeach (1973); the final version is from Schwartz (1994)).

A question is where values are located. There are two basic approaches: values form a special independent realm (esp. Max Scheler), or they are purely personal entities (esp. Jean Paul Sartre). We plead for the position of compromise laid out by Gabriel Marcel (1998): values are part of the transcendent area, yet can be manifested only as incarnate in human reality (Bednár., 2009). Values which are deeply rooted in the heart have the power to shape personality. This incarnational aspect, which has influenced personality, is the type of value which has true potential to influence the coaching process. This incarnational aspect is also reflected in how a coach defines success.

\section{Olympic values}

With that said there have been many attempts to implement values via sport. At this point we will review some of these efforts which would be expected to be reflected in at least the Czech sport context. The Olympic values are perhaps the most globally recognized and historically influential set of values we can see in sport. The Olympic values are a result of the long history of the Olympic Games beginning in antiquity. Epifaneia shows a close connection between the Olympic Movement and religion. The social dimension is manifested in the value of ekecheiria (Pax Olympica). Yet perhaps the most influential have been the two values aimed at the personal growth of the athletes: kalokagathia and arête. Both survive in modern Olympism. The former expressing a desire for harmony - was transformed in the contemporary Olympic Charter to read: "Olympism is [...] exalting and combining in a balanced whole the qualities of body, will and mind." The latter - expressing a desire for perfection - has found its continuation in the Olympic motto: "Citius - Altius - Fortius" (Faster Higher - Stronger).

Another part of the Olympic Charter speaks of the Olympic spirit, "which requires mutual understanding with a spirit of friendship, solidarity and fair play" (Fundamental principles of Olympism, № 4). Special attention is given to fair play which is a fruit of modern sport penetrating into wider society. We will return to fair play shortly. 


\section{Sokol values}

If we are to speak about values conveyance in Czech sport, then we must address the Sokol, or Falcon, Movement which heavily influenced the first republic of Czechoslovakia and the consequent development of sport therein. Sokol values were highlighted especially by the founder of Sokol, Miroslav Tyrš beginning in 1862 (Tyrš, 1926). He worked as a teacher of aesthetics, steeped in the old ideal of kalokagathia. Yet his new ideal was closer to that found in antiquity than that located within the Olympic Movement: harmony ought to be gained through proper balance of aesthetic and ethical values. It is not surprising that gymnastics (specially in their mass or collective form) was thus primary within this movement. The other supported values were health and courage with fitness, serving the goals of civil defence, not sport. This sport movement promoting Czech nationalism remained strong until being brutally suppressed, and then banned, by the Nazis and then the communists. We will return to examine the prevalence or lack thereof of each of these values today among Czech basketball coaches.

\section{Kretchmar values}

Philosophical synthesis in the field of sport and physical activities was brought by the American philosopher of sport, Scott Kretchmar. Kretchmar divided the corresponding values into two groups: basic (1) and moral (2) (1994).

Group (1) includes fitness, relevant knowledge, motoric skills and pleasure.

Fitness is seen here in relation to health and an active lifestyle; relevant knowledge is knowledge of our body, physical activities and health problems; pleasure ought to be part of well-being and is viewed as a result of proper challenge.

Group (2) includes trust, altruism, love, conscientiousness, courage, integrity, reputation and values forming the concept of fair play (friendship, respect of others, respect for rules, self-control). Kretchmar has identified here generally accepted and comprehensible values - the problem in the sport world lies in their "incarnation."

Kretchmar modified these with several shifts (2005): instead of fitness, health is named - intensive activities ought to be changed with less demanding but regular activities; instead of (only) motoric, relevant skills are named, and instead of pleasure fun is named (perhaps a reaction to the increasing penetration of the entertainment industry into sport?). The moral values from the second group are not changed, with the exception of the addition of the value of family friendly relations.

\section{Inherent, added and instrumental value}

Before we turn to the new emphasis on values-based leadership for organizational development, and our research results, we need to address the debate about the inherent versus added nature of values in sport. Martínková, who has written extensively on this topic, states that sport needs to have an educational component which includes "added" values, which she asserts arose from the humanistic aims of the Olympic Movement $(2012,2013)$. At the core of this distinction is a delineation between values arising from sports based on how they are played, and sport having value in and of itself. Fraleigh (1983) was one of the early advocates of sport having limited value in and of itself.

Fraleigh states that one of the few inherent values of sports is knowledge of relative abilities: 
The inherent value of the good sports contest is its capacity to provide complete and accurate knowledge of relative abilities to move mass in space and time and that capacity becomes a value because of its dependency upon the intrinsic value of the experience of quality of closure (Fraleigh, 1983, p. 56).

We see here again the use of the word "good" in connection with sports. Fraleigh draws a further classification of sport containing the potential for instrumental value in that it can serve a utilitarian economic, health, political or enjoyment value, but this is only possible when sport has a dependent value relation to these other values; they are not in and of themselves inherent in sport. Thus, US collegiate sport has a dependent relationship with education and thus collegiate sport can be said to have the potential for education. This value of education is thus measured relative to different programmes and schools, and the sport itself is in some form evaluated based on the fulfillment of this instrumental value. Even the values contained within the fair play movement, coming out of the Olympics and further defined by Kretchmar, can be termed as instrumental when viewed through the dependent relationship sport has with economics. The most economically profitable leagues are those with the most parity between teams. In order to achieve maximum parity between teams it is essential that the playing field is as fair as possible. Thus fair play actually becomes an instrumental value of profit as well as an inherent value of sport itself. The former president of the NCAA Brand's emphasis on fair play within the NCAA system can also be viewed as instrumental to university sport maintaining its privileged position in educational institutions (2006).

\section{Pragmatic benefit of values on performance}

The study of values in leadership is commonly found in social science research to be based on positive psychology, virtue ethics, and organizational scholarship. This movement has been termed values-based leadership. We examine it here because it both illustrates the instrumental value of values on performance, and proposes a pragmatic explanation of the use of values seen in NCAA basketball earlier. Studies from the business realm show that extraordinary individual and organizational effects are produced by emphasis on virtues, values and positivity (K. Cameron \& Dutton, 2003). At the individual level values-driven leadership has been found to produce physiological health benefits (e.g. less illness), emotional benefits (e.g. resistance to depression), and psychological benefits (e.g. longer memories) (K. S. Cameron \& Quinn, 2005). These characteristics make it attractive to companies wishing to achieve competitive advantage through their labor force. The research indicates that, at an organizational level, values-driven companies are found to have higher profitability, higher productivity, higher quality, and higher levels of satisfaction by both employees and customers. At the individual and organization level these results from value driven leadership need to be examined as per their potential effects on sport teams.

Kim Cameron has found that values-based leadership has an "amplifying effect" (2006). This type of amplifying effect would be a desired outcome on any sports team. The three factors contributing to this amplifying effect are positive emotions, social capital, and prosocial behaviour. Positive emotions are spread through the organization through a contagion effect when those in leadership positions display positive values (Camiré et al., 2014). This corresponds to our position that true values are 
incarnational. We will examine the potential application of these three contributing factors for coaches in the discussion section.

Olympism, Sokol, and the NCAA each added values onto sport in attempts to build character or create "good" sport. In spite of these efforts to add value to sport, the research appears clear that the current state of sport does not ensure "good" sport. The NCAA and fair play movements have instrumentally used values in order to achieve success, while attempting to hold onto the added benefit of character development. Whether or not this character development is successful is not the argument of this article, but rather is used in order to understand the use of values in the coaching process. It is argued that the NCAA coaches, having been heavily influenced by the business interests of sport, have instrumentally embraced the use of values in order to maintain competitive balance, increase productivity, and increase the satisfaction of athletes and fans alike. However, this coaching from a values-based framework is dependent on the incarnation of these values by the coach due to the amplification effect. Therefore, we will examine what values guide Czech basketball coaches in their coaching process, and what values they add or use instrumentally as they develop their athletes.

\section{METHODOLOGY}

This study was designed at the request of the Czech Basketball Federation in order to examine which values Czech basketball coaches are emphasizing at which age levels. Questions were constructed to progress from an open-ended perspective to a clarifying, application level. The purpose of this construction was that several within the basketball federation expected that coaches might lie in their initial responses in order to avoid embarrassment. By asking follow-up questions regarding application of the previously stated values, it was believed a more accurate picture of reality would emerge (Callary et al., 2013). The second portion of the survey provided the coaches with values to choose from based on those values recognised in sport by De Coubertin, Tyrš, the fair play movement, and Kretchmar. In using these particular values, it was hoped that we could negate or even eliminate what Kohlberg identified as a relativist "bag of virtues" (1981).

All surveys were conducted between January and May 2016. The introduction of the survey was done by a representative of the Czech Basketball Federation and completion of the survey was not mandatory. The response rate was $58 \%$ ( 73 surveys returned of 126 requested). Surveys were conducted in the Czech language by the primary researcher; interpretation and translation were conducted by both researchers.

\section{RESULTS AND DISCUSSION}

\section{Demographic data}

Table 1a Survey demographics (sex)

\begin{tabular}{lclc}
\hline & Sex of coach & \multicolumn{2}{c}{ Sex coached } \\
\hline Men & 52 & Men/boys & 48 \\
Women & 21 & Women/girls & 25 \\
\hline
\end{tabular}


Table 1b Survey demographics (age and experience)

\begin{tabular}{llllllll}
\hline Experience & \multicolumn{2}{l}{ Age } & & Age coached & \multicolumn{3}{l}{ Level coached } \\
\hline $1-4$ Yrs. & 24 & Age 19-25 & 18 & U8-U14 & 32 & Regional league & 21 \\
$5-9$ Yrs. & 16 & Age 26-33 & 12 & U15-U19 & 41 & Second league & 2 \\
$10-15$ Yrs. & 13 & Age 34-40 & 10 & Men/women & 9 & First league & 21 \\
$16-20$ Yrs. & 8 & Age 41-50 & 25 & & & Extraleague & 25 \\
$20+$ Yrs. & 12 & Age 51-62 & 6 & & & & \\
\hline
\end{tabular}

The average age of coaches surveyed was 36 . The average years coached was 11.4.

Table 1c Survey demographics (education)

\begin{tabular}{|c|c|c|c|c|c|}
\hline \multicolumn{2}{|c|}{ License level } & \multicolumn{2}{|c|}{ Education level } & \multicolumn{2}{|c|}{ Head or assistant coach } \\
\hline FIBA A & 20 & High school & 37 & Head & 56 \\
\hline FIBA B & 25 & University & 35 & Assistant & 17 \\
\hline FIBAC & 28 & $\mathrm{PhD}$ & 1 & & \\
\hline
\end{tabular}

The youngest FIBA A liscensed coach was 36 years old.

\section{Correlations}

Correlations occurred where we would naturally expect them: Older coaches have more experience (0.778), higher FIBA license (0.519), more education (0.4016) and are more likely to be head coaches (0.431). Those who have high levels of FIBA licensing have more experience (0.617), are more likley to be head coaches $(0.461)$ and coach on high levels (0.425). Additionally there was a higher correlation between sex of the coach and gender coached (0.498).

\section{Defining success}

Coaches were asked about success as the first and last question of the survey. At the beginning of the survey they were asked to define success as a coach, and at the conclusion they were asked what they considered to be success as a coach. These two questions were designed to discover why the coaches coached, or what they hoped to accomplish through their coaching. In this question we hoped to see the incarnational motivation of the coaches.

\section{Success generally}

The definitions of success (generally) identified can be divided into 3 main groups: player oriented (41 occurrences or 56\%), performance/achievement oriented (32 occurrences or $44 \%$ ), and coach oriented (8 occurrences or $11 \%$ ). (Because the question was open-ended some coaches wrote more than one response, thus there are more responses than the total number of surveys.) These responses are further extrapolated in Table 2 below. 
Table 2 Definitions of general coaching success

\begin{tabular}{|c|c|c|}
\hline Player oriented $56 \%$ & Performance/achievement oriented 44\% & Coach oriented $11 \%$ \\
\hline $\begin{array}{l}\text { Player development } \\
\text { - Continue with basketball }-8 \times \\
\text { - Skill mastery }-5 \times\end{array}$ & $\begin{array}{l}\text { Fulfill team goals (without concrete } \\
\text { description) - 10x }\end{array}$ & $\begin{array}{l}\text { Self-orientation }-6 \times \\
\text { - Do what I enjoy } \\
\text { - Do things excellently } \\
\text { - Reach my goals }\end{array}$ \\
\hline $\begin{array}{l}\text { Personal development } \\
\text { - Goal achievement satisfaction }-5 \times \\
\text { - Fulfill personal ambitions }-2 \times\end{array}$ & $\begin{array}{l}\text { Relevant knowledge leading to success - 10X } \\
\text { - Develop skills to win } \\
\text { - High quality games } \\
\text { - Ability to win important matches }\end{array}$ & $\begin{array}{l}\text { Positive player reaction }-2 \times \\
\text { - Players thank me } \\
\text { - Players give me credit }\end{array}$ \\
\hline Develop players for sport and life $-4 \times$ & Winning $-7 \times$ & \\
\hline $\begin{array}{l}\text { Experiences, Enjoyment } \\
\text { - Enjoyment of games and trainings }-9 \times \\
\text { - Enthusiasm and even love for } \\
\text { basketball }-5 \times \\
\text { - Joy of movement }-2 \times\end{array}$ & $\begin{array}{l}\text { Reach concrete result }-5 \times \\
\text { - Play-off } \\
\text { - Produce national team players } \\
\text { - Reach European level }\end{array}$ & \\
\hline
\end{tabular}

We can see here a general focus on player skill development and building the sport of basketball. In the player oriented responses, we can observe three tendencies: orientation on player development, personal development/growth, or on experience/joy of players. Yet even here the responses reveal that game development is more important than personal development for these coaches. And it must be emphasized from Table $1 \mathrm{~b}$ that 64 coaches from the 73 total respondents (88\%) work with youth teams. In the performance/achievement oriented responses, we observe two strong tendencies: fulfilling team goals, and orientation on know-how leading to team success; and then two lesser views: winning, and reaching concrete results. While many of these responses are focused on the individual players being coached, they are all based on the results achieved and the physical competence. Finally, in the coach oriented responses, we observe an orientation on the self and obtaining a positive response from players coached.

\section{Personal success}

The question of success was revisited at the end of the survey after coaches had seen the lists of value choices, and was asked from a more personal viewpoint. The responses for definitions of personal success can be divided into five main groups: oriented on sport growth or player engagement (20 occurrences or 30\%), oriented on the emotional dimension of players ( 18 occurrences or $27 \%$ ), oriented on the personal growth of players ( 6 occurrences or $9 \%$ ), performance/achievement oriented (13 occurrences or $19 \%$ ), coach oriented (10 occurrences or $15 \%$ ). Six coaches chose not to answer this question, thus the percentages are calculated from 67 total responses. It is evident that player oriented success from question one received a more nuanced response when coaches were asked to define the type of success they expect from themselves, thus we have divided it into three categories. If we combine these three player oriented categories: oriented on sport growth or player engagement, oriented on the personal growth of players, oriented on the emotional dimension of players, the response rate totals 
$66 \%$ of responses which is similar to the $56 \%$ observed when asked about coaching success generally. Detail of these responses is given in Table 3(a and b) below.

Table 3a Definitions of personal coaching success (player oriented)

\begin{tabular}{lll}
\hline Player oriented 66\% & & \\
\hline Player development or engagement 20\% & Emotional dimension of players 27\% & Personal growth of players 6\% \\
Skill mastery $-6 \times$ & Players enjoy games $-10 \times$ & Goal achievement \\
Good basketball foundation $-2 \times$ & Life-long love for sports $-3 \times$ & Healthy lifestyle \\
Remain in basketball $-7 \times$ & Joy from movement $-3 \times$ & Active lifestyle \\
Remain in sports $-4 \times$ & Satisfied teams $-2 \times$ & Respectful youth \\
& & Friendly relations \\
\hline
\end{tabular}

Table 3b Definitions of personal coaching success (performance and coach oriented)

\begin{tabular}{ll}
\hline Performance/achievement oriented 19\% & Coach oriented $15 \%$ \\
\hline Individual player success $-8 \times$ & Special coach $-7 \times$ \\
- Reach professional level & - Be a good promotor of sports \\
- Reach top Czech level & - Be a good basketball teacher \\
- Reach NBA level & - Be able to succeed with any team \\
& - Have many children at trainings \\
Fulfill team goals $-4 \times$ & Positive reaction from others $-3 \times$ \\
- Consistently reach play-offs & - Players show gratitude \\
-Win important matches & - Players give me credit \\
- High quality games & - Respect from other coaches \\
\hline Winning $-1 \times$ & \\
\hline
\end{tabular}

It was expected that results and game development would be more appreciated than personal growth - yet the disproportion is alarming: only 7 times was personal growth mentioned (once in combination with winning) from 67 answers altogether $(10 \%)$. That said, in both questions those who defined success by performance or achievement (45 cumulative responses) were primarily youth coaches. Only 4 total responses came from those coaching men or women at the professional level, representing 3 of the 9 professional level coaches represented. In the player oriented and coach oriented responses, we see a strong motivation among coaches to build into players a love for the game. There appears to be an incarnational desire to pass on their love for the game of basketball. We also see a more developmental motivation in the responses to this question than to the initial question asking them to define success.

\section{Values identified}

At this point we turn our attention to the values recognised. We began with two open-ended questions asking what values guide them as coaches, and what values they hope to develop in the team they are currently coaching. It was expected that the answers to the open-ended questions would more accurately reflect the true values of the coaches, while the closed questions would more likely expose the ideals of the coaches. We will compare these two types of questions, as well as compare across age coached, FIBA license level, education and sex. 


\section{What 3-5 values guide you as a coach?}

When asked to list the top 3-5 values which guide them, coaches listed on average 3.8 values. This was higher than the number of values they were able to list which they felt they could develop in their athletes (3.3). We have labeled these values as guiding values for the coaches. As seen in Table 4 below, respect appears to be the dominate guiding value of coaches, being mentioned 19 times. Several times the coaches were more specific with two types of respect mentioned, respect for others $(6 \times)$ and respect for the rules $(3 \times)$. This respect for the rules is very close to the value of fair play which coaches said they were often guided by $(12 \times)$. Fair play was also closely related to the value of fairness $(13 \times)$ where coaches expected themselves not to show preference between players. The values of hard work $(10 \times)$ and closely related diligence $(10 \times)$ were also very prominant in the guiding values of the coaches. Coaches stated that they beleived in team work, which they mentioned in different forms such as team spirit, team work, and team atmosphere. In order for team work to function there must be trust, thus the coaches listed this as a guiding value 9 times. The final value we will mention that showed prominance among all the coaches was fun, which only 9 of the 73 coaches listed as one of their 3-5 guiding values.

Table 4 Guiding values (age coached, open-ended)

\begin{tabular}{llllll}
\hline All (73) & U8-12 (15) & U13-14 (17) & U15-17 (19) & U19 (13) & Coaches of adult teams (9) \\
\hline Respect (19) & Respect (5) & Team work (4) & Respect (6) & Trust (4) & Fair play (3) \\
Fairness (13) & Fairness (3) & Respect (3) & Diligence (4) & Fairness (3) & Fairness (2) \\
Fair play (12) & Team work (3) & Courage (3) & Hard work (3) & Fair play (2) & Respect (2) \\
Hard work (10) & Humility (3) & Fun (3) & Fairness (3) & & Team work (2) \\
Diligence (10) & Trust (3) & Hard work (2) & Fair play (3) & & Friendliness (2) \\
Team work (11) & Hard work (2) & & Consistency (3) & Passion (2) \\
Trust (9) & & & & Fun (2) \\
Fun (9) & & & & \\
\hline
\end{tabular}

When we examine closer by the age group coached (in Table 4 above), we see that while respect is still prominent throughout, the younger coaches are governed by team work, humility and fun, while the coaches of the older age groups begin to emphasize hard work, diligence and fair play. It is significant that fun was pretty equally represented, even among the coaches for adult teams, while suprisingly missing from those coaching the youngest age groups. 
Table 5 Guiding values (certification and education, open-ended)

\begin{tabular}{lllll}
\hline FIBA A (20) & FIBA B (25) & FIBA C (28) & High school (37) & University (36) \\
\hline Respect (7) & Respect (6) & Fairness (5) & Trust (8) & Respect (11) \\
Fair play (5) & Fairness (5) & Trust (5) & Respect (7) & Fairness (9) \\
Fairness (3) & Fair play (3) & Humility (5) & Hard work (7) & Fair play (7) \\
Team work (4) & Diligence (3) & Hard work (4) & Diligence (6) & Team work (6) \\
Communication (3) & Hard work (2) & Diligence (2) & Team work (7) & Fun (5) \\
Consistency (3) & Team work (3) & Respect (4) & Fair play (5) & Diligence (4) \\
Hard work (0) & & Team work (3) & Fairness (4) & Consistency (4) \\
& & & Humility (4) & Hard work (3) \\
& & & Discipline (4) & \\
& & & Aggression (4) & \\
& & & Fun (4) & \\
\hline
\end{tabular}

When we examine the results in terms of licensing level (Table 5) we do not see significant differences beyond the mention of communication and lack of emphasis on hard work from the most qualified FIBA A coaches. Similarly the more educated coaches who had a university education mentioned hard work and diligence less frequenly than their only high school educated counterparts.

Table 6 Guiding values (sex, open-ended)

\begin{tabular}{llll}
\hline Male Coaches (52) & Female Coaches (21) & Coaches of males (48) & Coaches of females (25) \\
\hline Fair play (12) & Respect (8) & Fair play (10) & Respect (10) \\
Fairness (8) & Fairness (5) & Fairness (7) & Fairness (6) \\
Respect (9) & Team work (5) & Team work (8) & Team work (5) \\
Diligence (8) & Humility (4) & Hard work (8) & Trust (4) \\
Hard work (7) & & Diligence (7) & Patience (4) \\
Consistency (6) & & Respect (7) & \\
Fun (8) & & Fun (7) & \\
Team work (6) & Trust (5) & \\
Trust (6) & Aggression (5) & \\
& & Discipline (4) & \\
& & Humility (4) & \\
\hline
\end{tabular}




\section{What 3-5 values do you as a coach hope to develop in the team/players you are currently coaching?}

Table 7 Developmental values (age coached, open-ended)

\begin{tabular}{llllll}
\hline All (73) & U8-12 (15) & U13-14(17) & U15-17 (19) & U19 (13) & $\begin{array}{l}\text { Coaches of adult } \\
\text { teams (9) }\end{array}$ \\
\hline Team work (19) & Respect (4) & Team work (6) & Team work (5) & Team work (5) & Diligence (3) \\
Hard work (11) & Team work (3) & Respect (4) & Diligence (4) & Trust (3) & Respect (2) \\
Diligence (10) & Responsibility (3) & Hard work (3) & Hard work (3) & Communication & Perseverance (2) \\
Respect (11) & Fair play (2) & Responsibility (2) & Humility (4) & (2) & \\
Humility (10) & Humility (2) & Discipline (2) & Active (3) & Diligence (2) & \\
Responsibility (6) & Friendship (2) & Obedience (2) & Aggression (2) & Discipline (2) & \\
Active (6) & & Active (2) & Competitiveness & Respect (2) & \\
Friendship (6) & & Courage (2) & (2) & Humility (2) & \\
Fair play (5) & & & Honesty (2) & Competitiveness & \\
Discipline (5) & & & & (2) & \\
Motivation (5) & & & & & \\
Perseverance (5) & & & & & \\
& & & & & \\
\hline
\end{tabular}

We have termed these values which coaches hope to develop in their players as "developmental" values. The developmental values listed by coaches (Table 7) do not differ significantly from those which guide them. However, we see that team work and hard work, with its closely associated value of diligence, have replaced respect and fairness as top values. Respect and responsibility appear to be more important to those coaching younger athletes, while team work is relatively believed to be developmental at all age groups. We see less variation in developmental goals between licensing and education levels than we did among the coaches guiding values as illustrated in Table 8 below.

Table 8 Developmental values (certification and education, open-ended)

\begin{tabular}{lllll}
\hline FIBA A (20) & FIBA B (25) & FIBA C (28) & High school(37) & University (36) \\
\hline Team work (7) & Team work (10) & Responsibility (5) & Team work (13) & Team work (10) \\
Diligence (5) & Hard work (4) & Humility (5) & Humility (6) & Respect (6) \\
Discipline (4) & Diligence (3) & Hard work (3) & Hard work (6) & Hard work (5) \\
Hard work (3) & Respect (3) & Active (3) & Diligence (5) & Diligence (5) \\
Humility (3) & Competitive (3) & Respect (3) & Active (5) & Motivation (4) \\
& Fun (3) & & Aggressive (4) & Humility (4) \\
& & & Responsible (4) & \\
\hline
\end{tabular}


Table 9 Developmental values (sex, open-ended)

\begin{tabular}{llll}
\hline Male Coaches (52) & Female Coaches (21) & Coaches of males (48) & Coaches of females (25) \\
\hline Team work (19) & Responsible (5) & Team work (16) & Team work (7) \\
Hard work (9) & Team work (4) & Diligence (10) & Diligence (6) \\
Diligence (8) & Respect (3) & Hard work (9) & Responsibility (4) \\
Respect (8) & Humility (3) & Humility (8) & Competitiveness (3) \\
Humility (7) & Diligence (2) & Respect (7) & Friendship (3) \\
Discipline (5) & Hard work (2) & Fair play (5) & \\
Fair play (5) & Perseverance (2) & Aggression (4) & \\
Aggression (4) & Friendship (2) & Discipline (4) & \\
Motivation (4) & & Active (4) & \\
Active (4) & & & \\
Friendship (4) & & & \\
Fun (4) & & & \\
\hline
\end{tabular}

We will now compare these open-ended responses for top values to the closed responses from the surveys. The coaches were asked to mark up to five values which guide them as a coach, as well as up to five values which they would like to see developed in their players/team. The values which they had available to choose from were drawn from the Olympic Movement, the Sokol movement, the fair play movement, Kretchmar (1994, 2005), Christianity and the NCAA (Brand, 2006). For the sake of readability, Table 10 below only includes values ranked by $15 \%$ or more of the coaches. Values which were not ranked at all, or were ranked very low, will be referred to later. Of primary significance to us are the top ranked values and the values which coaches chose not to value.

In Table 10 we see even more clearly than in the open ended questions that Czech basketball coaches hold hard work, an inherent value required to improve in sport, as their highest value ( $40 \%$ and $37 \%$ ), both as the value that guides them as coaches and that which they hope to develop in their athletes. In every age category coached except the youngest U8-12, where health leads values with $60 \%$, hard work is one of the top five values guiding coaches and which they hope to develop. Most of the time hard work is the top value. Where we see exception to this is with women coaches who value friendship (43\%) and fun (38\%) as guiding values, and winning and losing with grace (48\%) as a developmental value higher than hard work (33\% and $43 \%$ ). It is also interesting that those with a university education, just under $50 \%$ of respondents, also had a higher value than hard work, though hard work remained in their top five.

Respect for others, a value of the fair play movement, is the second highest ranked value (34\% and $26 \%$ ), and if we combine it with respect for the rules (21\% and $14 \%$ ), then it would again be the top value for coaches as it was in the open-ended questions where respect for what was often not specified. 
Table 10 Top ranked values $(>15 \%)$

\begin{tabular}{|c|c|c|c|c|c|c|c|c|c|c|c|c|c|c|c|}
\hline & Frequency & $\mathrm{N}$ & 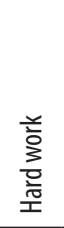 & 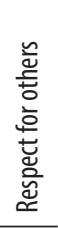 & 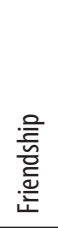 & 产 & 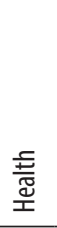 & 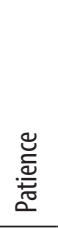 & 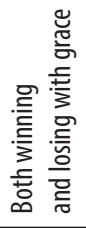 & 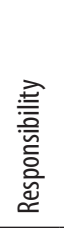 & 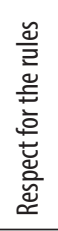 & $\begin{array}{l}\text { 謩 } \\
\text { 产 }\end{array}$ & 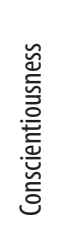 & $\stackrel{\underline{\underline{n}}}{\underline{\underline{s}}}$ & 岕 \\
\hline Total & Guiding & 73 & $40 \%$ & $34 \%$ & $33 \%$ & $33 \%$ & $27 \%$ & $26 \%$ & $23 \%$ & $21 \%$ & $21 \%$ & $19 \%$ & $16 \%$ & $16 \%$ & $16 \%$ \\
\hline Total & Developing & 73 & $37 \%$ & $26 \%$ & $29 \%$ & $18 \%$ & $25 \%$ & $11 \%$ & $33 \%$ & $30 \%$ & $14 \%$ & $19 \%$ & $15 \%$ & $11 \%$ & $7 \%$ \\
\hline Total & Both & 73 & $19 \%$ & $12 \%$ & $14 \%$ & $7 \%$ & $11 \%$ & $1 \%$ & $7 \%$ & $10 \%$ & $5 \%$ & $10 \%$ & $5 \%$ & $1 \%$ & $4 \%$ \\
\hline
\end{tabular}

Sex

$\begin{array}{llllllllllllllll}\text { Male coaches Guiding } & 52 & 42 \% & 38 \% & 29 \% & 31 \% & 29 \% & 23 \% & 21 \% & 25 \% & 19 \% & 13 \% & 15 \% & 17 \% & 15 \%\end{array}$ $\begin{array}{llllllllllllllll}\text { Male coaches Developing } & 52 & 37 \% & 21 \% & 25 \% & 15 \% & 25 \% & 10 \% & 27 \% & 25 \% & 12 \% & 17 \% & 15 \% & 12 \% & 6 \%\end{array}$ Female $\begin{array}{llllllllllllllll}\text { coaches } & \text { Guiding } & 21 & 33 \% & 24 \% & 43 \% & 38 \% & 24 \% & 33 \% & 29 \% & 10 \% & 24 \% & 33 \% & 19 \% & 14 \% & 19 \%\end{array}$

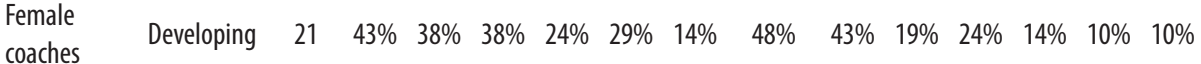

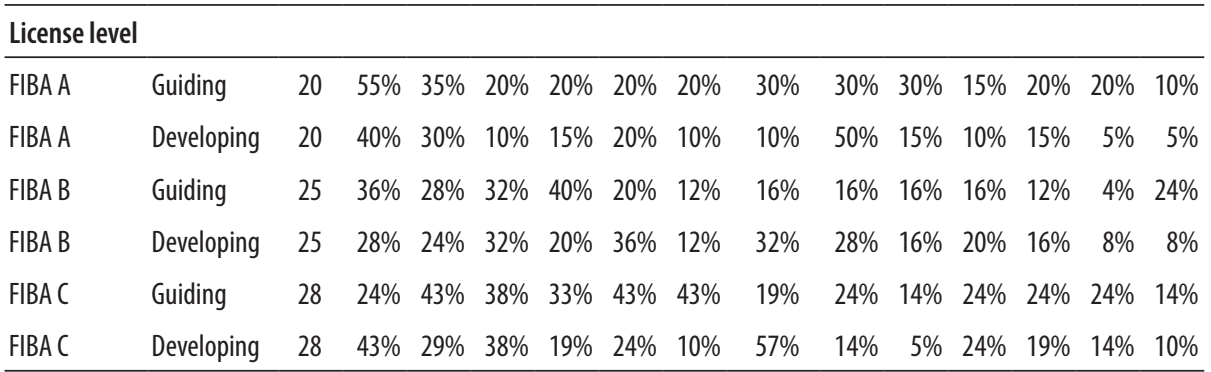

Education

\begin{tabular}{llllllllllllllll}
\hline High School & Guiding & 37 & $51 \%$ & $41 \%$ & $32 \%$ & $41 \%$ & $38 \%$ & $35 \%$ & $27 \%$ & $19 \%$ & $19 \%$ & $24 \%$ & $8 \%$ & $16 \%$ & $16 \%$ \\
High School & Developing & 37 & $35 \%$ & $16 \%$ & $32 \%$ & $16 \%$ & $24 \%$ & $11 \%$ & $19 \%$ & $22 \%$ & $16 \%$ & $27 \%$ & $11 \%$ & $11 \%$ & $8 \%$ \\
University & Guiding & 36 & $28 \%$ & $28 \%$ & $33 \%$ & $25 \%$ & $17 \%$ & $17 \%$ & $19 \%$ & $22 \%$ & $22 \%$ & $14 \%$ & $25 \%$ & $17 \%$ & $17 \%$ \\
University & Developing & 36 & $42 \%$ & $36 \%$ & $25 \%$ & $19 \%$ & $28 \%$ & $11 \%$ & $47 \%$ & $39 \%$ & $11 \%$ & $11 \%$ & $19 \%$ & $11 \%$ & $6 \%$ \\
\hline Sex coached & & & & & & & & & & & & & & \\
\hline Males & Guiding & 52 & $40 \%$ & $33 \%$ & $35 \%$ & $31 \%$ & $29 \%$ & $21 \%$ & $27 \%$ & $23 \%$ & $21 \%$ & $21 \%$ & $15 \%$ & $19 \%$ & $13 \%$ \\
Males & Developing & 52 & $44 \%$ & $19 \%$ & $25 \%$ & $19 \%$ & $27 \%$ & $13 \%$ & $35 \%$ & $25 \%$ & $15 \%$ & $21 \%$ & $19 \%$ & $15 \%$ & $6 \%$ \\
Females & Guiding & 21 & $40 \%$ & $36 \%$ & $28 \%$ & $36 \%$ & $24 \%$ & $36 \%$ & $16 \%$ & $16 \%$ & $20 \%$ & $16 \%$ & $20 \%$ & $12 \%$ & $24 \%$ \\
Females & Developing & 21 & $28 \%$ & $40 \%$ & $36 \%$ & $16 \%$ & $24 \%$ & $8 \%$ & $24 \%$ & $40 \%$ & $12 \%$ & $16 \%$ & $8 \%$ & $4 \%$ & $8 \%$ \\
\hline Age coached & & & & & & & & & & & & & & \\
\hline U8-12 & Guiding & 15 & $20 \%$ & $27 \%$ & $47 \%$ & $40 \%$ & $60 \%$ & $47 \%$ & $13 \%$ & $7 \%$ & $7 \%$ & $27 \%$ & $27 \%$ & $13 \%$ & $20 \%$ \\
U8-12 & Developing & 15 & $40 \%$ & $20 \%$ & $40 \%$ & $20 \%$ & $33 \%$ & $27 \%$ & $40 \%$ & $27 \%$ & $13 \%$ & $13 \%$ & $0 \%$ & $7 \%$ & $7 \%$ \\
U13-14 & Guiding & 17 & $59 \%$ & $35 \%$ & $35 \%$ & $53 \%$ & $47 \%$ & $29 \%$ & $29 \%$ & $35 \%$ & $29 \%$ & $12 \%$ & $12 \%$ & $18 \%$ & $6 \%$
\end{tabular}




\begin{tabular}{llllllllllllllll} 
U13-14 & Developing & 17 & $47 \%$ & $12 \%$ & $41 \%$ & $18 \%$ & $29 \%$ & $12 \%$ & $35 \%$ & $18 \%$ & $18 \%$ & $24 \%$ & $18 \%$ & $24 \%$ & $6 \%$ \\
U15-17 & Guiding & 19 & $32 \%$ & $47 \%$ & $26 \%$ & $32 \%$ & $5 \%$ & $26 \%$ & $32 \%$ & $26 \%$ & $16 \%$ & $21 \%$ & $26 \%$ & $21 \%$ & $21 \%$ \\
U15-17 & Developing & 19 & $37 \%$ & $26 \%$ & $21 \%$ & $11 \%$ & $21 \%$ & $11 \%$ & $32 \%$ & $42 \%$ & $11 \%$ & $26 \%$ & $26 \%$ & $0 \%$ & $5 \%$ \\
U19 & Guiding & 13 & $46 \%$ & $31 \%$ & $38 \%$ & $8 \%$ & $15 \%$ & $8 \%$ & $15 \%$ & $8 \%$ & $38 \%$ & $31 \%$ & $8 \%$ & $23 \%$ & $23 \%$ \\
U19 & Developing & 13 & $31 \%$ & $38 \%$ & $15 \%$ & $15 \%$ & $15 \%$ & $0 \%$ & $31 \%$ & $31 \%$ & $15 \%$ & $23 \%$ & $8 \%$ & $23 \%$ & $8 \%$ \\
\hline Adult teams & Guiding & 9 & $44 \%$ & $22 \%$ & $11 \%$ & $22 \%$ & $0 \%$ & $11 \%$ & $22 \%$ & $22 \%$ & $11 \%$ & $0 \%$ & $0 \%$ & $0 \%$ & $11 \%$ \\
Adult teams & Developing & 9 & $33 \%$ & $44 \%$ & $22 \%$ & $33 \%$ & $33 \%$ & $0 \%$ & $22 \%$ & $33 \%$ & $11 \%$ & $0 \%$ & $22 \%$ & $0 \%$ & $11 \%$ \\
\hline
\end{tabular}

The other values which make up the top five guiding values for coaches, friendship (33\%), fun (33\%) and health (27\%), were hardly observed when coaches were asked the open-ended questions. (Health was never mentioned.) Perhaps this is because the coaches take them for granted and subconsciously value them automatically. More likely, they are not true guiding values for the coaches, but rather they know intellectually that they should be guided by these values, especially fun and health. Of these three, friendship (29\%) is the only one that is ranked in the top five of the values they hope to develop in their athletes, though both, particularly health (25\%) are still ranked highly. Friendship is seen to decrease in percentage as coaches advance in license level (FIBA C $38 \%$ and $38 \%$, FIBA B $32 \%$ and $32 \%$, FIBA A $20 \%$ and $10 \%$ ). Female coaches and those coaching female teams placed higher value in friendship than their male counterparts or those coaching male teams. Also, the value of friendship became less important as the age coached went up, with the exception of those coaching adult teams (developmental percentages: U8-12, 40\%; U13-14, 41\%; U15-17, $21 \%$; U19, $15 \%$; adult, $22 \%$ ). The value of fun follows a similar pattern in that it is more important to women coaches, and becomes less important as the age coached increases, but only to the U19 category (developmental percentages: U8-12, 20\%; U13-14, 18\%; U15-17, 11\%; U19, 15\%; adult, 33\%). Health is the most significant guiding value for the youngest group of youth coaches at $60 \%$, and follows the same pattern of decreasing in importance as the age category coached increases, until we get to the adult age (developmental percentages: U8-12, 33\%; U13-14, 29\%; U15-17, $21 \%$; U19, 15\%; adult, 33\%). It is expected that the high ranking of these values among coaches of adult teams, even though they decreased as age categories increased, can be attributed to there being only two extra-league coaches among those coaching adult teams. Thus these coaches of adult teams are not coaching professional teams, so they must instrumentally value friendship, fun and health in order to keep players playing, since these teams are not professional.

The difference between male and female coaches has been mentioned above, but it is worthy of being expounded on. The top five values for men, representing $71 \%$ of the coaches surveyed is the same as the full sample: hard work (42\%), respect for others $(38 \%)$, fun (31\%), friendship and health (both $29 \%$ ). Women coaches, however, expressed a slightly different set of values: friendship (43\%), fun (38\%), hard work, patience, and humility (all 33\%). Similarly, they differ in values they hope to develop in their players: male coaches (hard work $37 \%$, winning and losing with grace $27 \%$, friendship, health, and responsibility all 25\%), and female coaches (winning and losing with grace $48 \%$, hard work and responsibility both $43 \%$, respect for others and 
friendship 38\%). Significantly, the women coaches also indicated much higher percentages of desiring to develop the added moral values of bravery (19\% women to $8 \%$ men), love ( $10 \%$ women to $2 \%$ men), and hope ( $14 \%$ women to $4 \%$ men). However, there is not so much difference found between those who coach opposite sexes. Here we see the previously mentioned higher emphasis on respect for others and friendship by those coaching women as compared to men, and an increased desire to develop responsibility in those coached ( $40 \%$ for females and $25 \%$ for males). Finally, it appears that those coaching females are guided more by fairness (24\%) than those coaching males (13\%).

Table 11 Values not valued

\begin{tabular}{llll}
\hline Guiding Values & \multicolumn{3}{l}{ Developmental Values } \\
\hline Resilience & $5 \%$ & Self-control & $5 \%$ \\
Striving for excellence & $5 \%$ & Relevant knowledge & $5 \%$ \\
Relevant knowledge & $5 \%$ & Faith & $4 \%$ \\
Morality & $5 \%$ & Love & $4 \%$ \\
Civility & $4 \%$ & Morality & $4 \%$ \\
Hope & $4 \%$ & Integrity & $3 \%$ \\
Family friendly relationships & $4 \%$ & Strength & $3 \%$ \\
Relevant skills & $4 \%$ & Unselfishness & $3 \%$ \\
Reputation & $3 \%$ & Wisdom & $3 \%$ \\
Integrity & $1 \%$ & Family friendly relationships & $1 \%$ \\
Unselfishness & $1 \%$ & Mental and body balance & $1 \%$ \\
Wisdom & $1 \%$ & Relevant skills & $1 \%$ \\
Mental and body balance & $1 \%$ & Reputation & $0 \%$ \\
Balanced life & $1 \%$ & Balanced life & $0 \%$ \\
Strength & $0 \%$ & Welfare & $0 \%$ \\
Welfare & $0 \%$ & & \\
\hline
\end{tabular}

\section{DISCUSSION}

We will first evaluate the values cited as per their source, Olympism, Sokol, Fair Play, Kretchmar, and the NCAA, as they illustrate for us the changing of values globally in sport through time. The values of the Fair Play movement and those codified by the NCAA and Kretchmar are dominant among Czech basketball coaches. As illustrated in Table 11, those promoted by Miroslav Tyrš in the Sokol movement and Pierre de Coubertin occupy the lower rankings along with those of Christianity. It is interesting to note that these three movements, Christianity, Olympism and Sokol have primarily tried to add values into sport to suit their purposes. The NCAA and the Fair Play movement also desire to shape sport in a particular direction, but the values they promote are either inherent to sport or instrumental to sport. This instrumentality pragmatically flows out of the definitions of success offered by the coaches, where we saw that individual player development, performance and building a love for the game dominated. Given the development of sport as a business which has occurred in the Czech context (as well as globally although later) this should not surprise us. 
It is evident from the leading values of hard work, respect, fairness and diligence that the majority of Czech coaches are firmly rooted in the inherent values of sport. Instrumental values come into play in order to increase team work which flows out of their desire for performance or achieving team goals. Other instrumental values such as friendship, fun, patience and humility are relied upon depending on age and gender coached, and appear to increase with education and licensing. However, the added values evidenced in Olympism, the Sokol movement or Christianity are largely absent in Czech basketball. This lack of added values was also visible in the almost non-existence of sport as a builder of character, or "good sport" from the definitions of success given by the Czech coaches.

\section{Values-based coaching as a prescription}

This study has its germination in a group of Czech coaches visiting NCAA basketball programmes. Thus at this point we will attempt to understand why the NCAA programmes appear to be guided by a higher prevalence of instrumental and even added values. We will rely on the values-based leadership model introduced previously to explain this and consequently propose that this model could in fact help reach the success which the Czech coaches indicated they desire.

Both sets of coaches, Czech and NCAA, desire to develop individual players, which leads to reaching team goals. Both of these contribute to the success and recognition of the coach. In terms of the NCAA coach he will receive a higher salary, and be able to recruit better players if he achieves success. The Czech coach is trying to produce national team and professional players. The NCAA coach is dependent on recruiting and the Czech coach is developing players who will move up within age categories of the club. The NCAA coach is only dealing with players aged 18-24, while the Czech coaches are dealing with all age categories. Yet the NCAA coaches have many more athletes to choose from, and more competitive balance than the Czech coaches. However, for both of them, developing players leads to an increased likelihood of reaching team goals which may result in coach recognition.

So why is values-driven coaching so much more prevalent in the NCAA context and largely absent from the Czech context, and of what benefit is it in achieving success? The NCAA, which exists within the university system, is a highly profitable enterprise (almost topping \$1billion dollars in 2014). Thus they have borrowed the best practices from business and applied them to sport in order to succeed. Czech sport, just over 20 years removed from socialism, has not been exposed to these business impulses to as high a degree, and it is removed from the educational sector.

Cameron \& Quinn assert that, in the workplace, values-driven leadership has been found to produce physiological health benefits (e.g. less illness), emotional benefits (e.g. resistance to depression), psychological benefits (e.g. longer memories) (Cameron \& Quinn, 2005). If we were to extrapolate this out to the sport team environment, we could speculate that teams with value driven coaches would be less likely to have player injury and sickness; their players would be more likely to recover from defeat and be less affected by inconsistent referees; and be more likely to remember team plays and respond to scouting reports (Peel et al., 2013). Koh et al. found similar results among youth in Singapore school sport (2016). If, at the organizational level, values-driven companies are found to have higher profitability, higher productivity, 
higher quality, and higher levels of satisfaction by both employees and customers, then we extrapolate that values-led teams can expect more wins, more effective practices, better concentration, and greater loyalty between teammates and from fans.

Applying Cameron's amplifying effect to the incarnational role of values in the role of a coach, we can postulate the positive effect on a sports team or organization. Cameron identified the three factors contributing the amplifying effect as positive emotions, social capital, and prosocial behaviour (Hess \& Cameron, 2006). While we have termed this as incarnational, Cameron terms it a contagion effect with the first amplified value to be positive emotions. For example, Cameron found that when leaders value compassion, love and highlight spectacular performance, then employees are inspired; their organizational pride increases; their work enjoyment is increased, and their job satisfaction is elevated. Inspired players, club pride, enjoyment of practice and games, and club satisfaction are values that any sport club would like to see and was even partially expressed in our results. These are all positive emotions which appear to have a high correlation to leaders/coaches who demonstrate the values they espouse (Callary et al., 2013; Peel et al., 2013). Unfortunately, compassion and love remain on the list of values which Czech coaches do not value.

Cameron's second factor that contributes to the amplifying effect of leaders who are value driven is social capital (Hess \& Cameron, 2006). Social capital is the development of positive relationships between employees. In sport terms social capital is good team cohesion, a value expressed by the majority of Czech basketball coaches in one form or another. The use of values in building team cohesion could mean coaches can more easily motivate players, get players to communicate with each other and work together, be more committed to the team, be motivated to learn on their own, and win more often.

The third factor Cameron found when leaders incarnationally display the positive values they desire to see is prosocial behaviour. Prosocial behaviour is the tendency to engage in helpful behaviour toward others, or to want to make a contribution to others (Hess \& Cameron, 2006). This is an intrinsic motivation to help others; which was evident in the wording of values from the NCAA teams, but almost completely lacking among Czech basketball coaches. Servanthood, servant-leadership, selflessness (all seen in the illustrative NCAA examples) are some of the values which lead to this prosocial behaviour which produces trust and speeds up both the individual and team development process. When players observe and believe that their coach truly desires to help them, then they are more likely to help their teammates. Values-led leadership can help reduce the cancer to selfishness in sport. This prosocial behaviour builds character and leads to positive sport.

\section{CONCLUSION}

By surveying Czech basketball coaches we have assessed the use of values in the coaching process as well as the origin of these values-based on their definitions of success. In contrast to the NCAA basketball coaches who instrumentally use values to guide them and develop their players, Czech coaches rely primarily on the inherent values of sport such as hard work and respect. While many movements such as the Olympics, Sokol and even the NCAA have attempted to encourage added values in sport in order to 
build character or create "good" sport, it has been argued that coaches are more likely to instrumentally use values in a pragmatic effort to maintain competitive balance, player and fan satisfaction, and increase productivity. The Czech coaches are guided by their achievement goal of success and their desire to build the sport of basketball in their culture. However, with only a few exceptions, sport appears to have little to no added positive value for them, and so they do not rely on moral values in their coaching process. It is argued that the use of values-driven coaching, as was evidenced in the NCAA, and as developed in business, could help Czech coaches to reach their performance and achievement goals, and further develop the sport. This pragmatic instrumentality of values, which appears to come with the commercialization of sport, is regulated by the incarnation of these values by the coach and the consequent amplification by his/her athletes. Thus the successful implementation of moral values by a coach in order to produce the desired positive emotions, social capital, and prosocial behaviour on his/her team appears to be wedded to the character of the coach.

\section{REFERENCES}

Baier, K. (1965). The moral point of view: A rational basis of ethics (Abridged edition). Random House.

Bednář, M. (2009). Pohyb člověka na biodromu: cesta životem z pohledu (nejen) kinantropologie. Prague: Karolinum.

Beller, J. M., \& Stoll, K. S. (1995). Moral reasoning of high school student athletes and general students: An empirical study versus personal testimony. Pediatric Exercise Science, 7(4), $352-363$.

Brand, M. (2006). The role and value of intercollegiate athletics in universities. Journal of the Philosophy of Sport, 33(1), 9-20.

Bredemeier, B. J., Weiss, M. R., Shields, D. L., \& Cooper, B. A. (1987). The relationship between children's legitimacy judgments and their moral reasoning, aggression tendencies, and sport involvement. Sociology of Sport Journal, 4(1), 48-60.

Burton, L., \& Welty Peachey, J. (2014). Ethical leadership in intercollegiate sport: Challenges, opportunities, future directions. Journal of Intercollegiate Sport, 7(1), 1-10.

Callary, B., Werthner, P., \& Trudel, P. (2013). Exploring coaching actions based on developed values: a case study of a female hockey coach. International Journal of Lifelong Education, 32(2), 209-229.

Cameron, K., \& Dutton, J. (2003). Positive organizational scholarship: Foundations of a new discipline. San Francisco: Berrett-Koehler Publishers.

Cameron, K. S., \& Quinn, R. E. (2005). Diagnosing and changing organizational culture: Based on the competing values framework. John Wiley \& Sons.

Camiré, M., Trudel, P., \& Forneris, T. (2014). Examining how model youth sport coaches learn to facilitate positive youth development. Physical Education and Sport Pedagogy, 19(1), 1-17.

Crone, J. A. (1999). Toward a theory of sport / Vers une theorie du sport. Journal of Sport Behaviour, 22(3), 321-340.

Dean, K. W. (2012). Values-based leadership: How our personal values impact the workplace. The Journal of Values-Based Leadership, 1(1), 9.

DeSensi, J. T. (2010). Ethics and Morality in Sport Management (3rd edition). Morgantown: Fitness Information Technology.

Doty, J. (2006). Sports build character?! Journal of College and Character, 7(3), 1-9.

Duda, J. L., Balaguer, I., Jowett, S., \& Lavallee, D. (2007). Coach-created motivational climate. In: Social psychology in sport (pp. 117-130). Champaign, IL: Human Kinetics. 
Fernandez, J. E., \& Hogan, R. T. (2002). Values-based leadership. The Journal for Quality and Participation, 25(4), 25.

Fraleigh, W. P. (1983). An examination of relationships of inherent, intrinsic, instrumental, and contributive values of the good sports contest. Journal of the Philosophy of Sport, 10(1), $52-60$.

Gerdy, J. R. (2000). Sports in School: The Future of an Institution. London: Teachers College Press.

Grojean, M. W., Resick, C. J., Dickson, M. W., \& Smith, D. B. (2004). Leaders, values, and organizational climate: Examining leadership strategies for establishing an organizational climate regarding ethics. Journal of Business Ethics, 55(3), 223-241.

Hassanin, R., \& Light, R. (2014). The influence of cultural context on rugby coaches' beliefs about coaching. Sports Coaching Review, 3(2), 132-144.

Hess, E. D., \& Cameron, K. S. (2006). Leading with Values: Positivity, Virtue and High Performance. Cambridge: Cambridge University Press.

Janssen, J., \& Dale, G. (2002). The Seven Secrets of Successful Coaches (58806th edition). Cary, NC: Janssen Peak Performance Inc.

Josephson Institute. (2006). What Are Your Children Learning? The Impact of High School Sports on the Values and Ethics of High School Athletes. Retrieved from http://sports.josephsoninstitute.org/programs-sport/survey-program.

Kleiber, D. A., \& Roberts, G. C. (1981). The effects of sport experience in the development of social character: An exploratory investigation. Journal of Sport Psychology, 3(2).

Kluckhohn, C. (1951). Values and value-orientations in the theory of action: An exploration in definition and classification. In: T. Parsons \& E. Shils (Eds.), Toward a General Theory of Action (pp. 388-433). Cambridge, MA: Harvard University Press.

Koh, K. T., Ong, S. W., \& Camiré, M. (2016). Implementation of a values training program in physical education and sport: perspectives from teachers, coaches, students, and athletes. Physical Education and Sport Pedagogy, 21(3), 295-312.

Kohlberg, L. (1981). Essays on moral development: The psychology of moral development (Vol. 1). San Francisco: Harper \& Row.

Kretchmar, R. S. (1994). Practical Philosophy of Sport. Champaign, IL: Human Kinetics.

Kretchmar, R. S. (2005). Practical Philosophy of Sport and Physical Activity. Champaign, IL: Human Kinetics.

Lumpkin, A., Stoll, S. K., \& Beller, J. (2002). Sport Ethics: Applications for Fair Play (3rd edition). McGraw-Hill Humanities/Social Sciences/Languages.

Marcel, G. (1998). Homo Viator Prolégomènes À Une Métaphysique de L'Espérance. Association Présence de Gabriel Marcel.

Martínková, I. (2012). Teaching Values in Movement Activities: Inherent and Added Values. Acta Universitatis Carolinae. Kinanthropologica, 48(2), 111-119.

Martínková, I. (2013). Instrumentality and Values in Sport. Prague: Karolinum Press.

May, R. A. B. (2001). The Sticky Situation of Sportsmanship Contexts and Contradictions in Sportsmanship among High School Boys Basketball Players. Journal of Sport \& Social Issues, 25(4), 372-389.

Parry, J. (2010). Sport, ethos and education. In: M. J. McNamee (Ed.), The ethics of sports: a reader (pp. 316-326). Routledge, Taylor \& Francis.

Peel, J., Cropley, B., Hanton, S., \& Fleming, S. (2013). Learning through reflection: values, conflicts, and role interactions of a youth sport coach. Reflective Practice, 14(6), 729-742.

Rees, C. R., Howell, F. M., \& Miracle, A. W. (1990). Do high school sports build character? A quasi-experiment on a national sample. The Social Science Journal, 27(3), 303-315.

Rokeach, M., et al. (1973). The nature of human values (Vol. 438). Free press New York.

Russell, J. S. (2011). The Moral Ambiguity of Coaching Youth Sport. In: A. R. Hardman \& C. Jones (Eds.), The Ethics of Sports Coaching. London: Routledge, 87-103. 
Sagas, M., \& Wigley, B. J. (2014). Gray Area Ethical Leadership in the NCAA: The Ethics of Doing the Wrong Things Right. Journal of Intercollegiate Sport, 7(1).

Sage, G. (1998). Does sport affect character development in athletes? Journal of Physical Education, Recreation \& Dance, 69(1), 15-18.

Schwartz, S. H. (1994). Are there universal aspects in the structure and contents of human values? Journal of Social Issues, 50(4), 19-45.

Stoll, K. S., \& Beller, J. M. (2012). Moral Reasoning in Athlete Populations - a 30 Year Review. Retrieved March 9, 2016, from https://www.webpages.uidaho.edu/center_for_ethics /research_fact_sheet.htm.

Stupuris, T., ك̌́ukys, S., \& Tilindienè, I. (2013). Relationship Between Adolescent Athletes' Values and Behaviour in Sport and Perceived Coach's Character Development Competency. Education. Physical Training. Sport, 91(4), 37-45.

Tyrš, M. (1926). Tělocvik v ohledu esthetickém. Knihovna Tyršův odkaz.

Lai, Yi-Ling, \& McDowall, A. (2014). A systematic review (SR) of coaching psychology: Focusing on the attributes of effective coaching psychologists. International Coaching Psychology Review, 9(2), 118-134. 